\title{
TROSKA BENEDYKTA XVI O KAPŁANÓW JAKO SZAFARZY SAKRAMENTU MIŁOSIERDZIA
}

Ogłaszając Nadzwyczajny Jubileusz Miłosierdzia papież Franciszek wzywał, by na nowo postawić w centrum sakrament pokuty i pojednania, ponieważ pozwala on namacalnie przekonać się o wielkości Bożego miłosierdzia i doświadczyć prawdziwego wewnętrznego pokoju. Zadanie to powierzył w szczególności spowiednikom ${ }^{1}$. Od ich odpowiedniego przygotowania, a właściwie od permanentnej formacji, zależeć będzie w dużej mierze realizacja tego zadania. Św. Jan Paweł II zwrócił na to szczególną uwagę w posynodalnej adhortacji Reconciliatio et paenitentia. Podkreślił w niej m.in., że spowiednik, posiadając odpowiednie ludzkie przymioty, powinien prowadzić głębokie życie duchowe, musi sam pierwszy iść drogą pokuty oraz dbać o własne doskonalenie się i odnowę poprzez stałe dokształcanie się ${ }^{2}$ Papież przypominał o tym wielokrotnie podczas spotkań ze spowiednikami biorącymi udział w kursach organizowanych przez Penitencjarię Apostolską. Jego wypowiedzi z okazji kilkunastu takich spotkań są ciągle aktualnym pouczeniem oraz inspiracją dla spowiedników. Stały się one także przedmiotem odrębnych opracowań3 3 .

${ }^{1}$ Por. Fr a n c is z e k, Bulla Misericordiae Vultus (Watykan, 11.04.2015), nr 17.

2 Por. J a n P aweł II, Adhortacja apostolska Reconciliatio et paenitentia, nr 29.

${ }^{3}$ Por. J. A u g u st y n, Naśladować Jezusa w konfesjonale, w: Tenże (red.) Sztuka spowiadania. Poradnik, Kraków 2012, s. 253-261; B. J u r c z y k, Potrójna 
Papież Benedykt XVI podtrzymał tradycję spotkań ze spowiednikami, podczas których podkreślał znaczenie sakramentu pokuty i pojednania. Przypominając zadania szafarza zwykle akcentował jakiś element jego posługi oraz zwracał uwagę na kontekst kulturowy, w którym się ona dokonuje. Także ogłoszony przez ojca św. Rok Kapłański był szczególną okazją do zabierania głosu na ten temat. $\mathrm{W}$ ten sposób Benedykt XVI ofiarował spowiednikom wsparcie i przekazał bogaty materiał do refleksji. W niniejszym artykule ukazana zostanie troska ojca świętego o kapłanów jako szafarzy sakramentu miłosierdzia. Najpierw podkreślona zostanie rola dorocznych spotkań z Penitencjarią Apostolską, następnie przywołane będą wypowiedzi z Roku Kapłańskiego, a na koniec omówione zostaną najważniejsze wskazania dokumentu Kongregacji ds. Duchowieństwa Kapłanszafarz miłosierdzia Bożego.

\section{SPOTKANIA Z PENITENCJARIĄ APOSTOLSKĄ}

Papież Benedykt XVI kontynuował działania swego poprzednika i regularnie spotykał się z penitencjarzami i uczestnikami kursów na temat forum wewnętrznego, które organizuje Panitencjaria Apostolska. Wskazanie na istotne elementy papieskiego nauczania warto poprzedzić przypomnieniem, że św. Jan Paweł II ze względu na stan zdrowia nie mógł już osobiście uczestniczyć w ostatnim takim spotkaniu podczas swojego pontyfikatu. Z Polikliniki Gemellego, 8 marca 2005 r. skierował przesłanie do uczestników kursu, w którym zwrócił uwagę na związek sakramentu pojednania z Eucharystią.

rola kapłana $w$ sakramencie pokuty, w: K. Glombik (red.), Sakrament pokuty wobec problemów wspótczesności, Opole 2011, s. 217-238; J. S z y m a ń s k i, Kapłan sługa sakramentalnego pojednania, „Ateneum Kapłańskie”, t. 154 (2010) z. 3, s. 249-260; Z. W a n a t, Kapłan-spowiednik-sługa miłości potężniejszej niż grzech, „Teologia i Człowiek”, (2006) nr 1-2, s. 271-288; Tenże, Kapłan - sługa Bożego miłosierdzia, „Studia Theologica Varsaviensia”, 52(2014) nr 2, 83-102; J. O r z e s z y n a, Posłannictwo i obowiazki spowiednika w nauczaniu Jana Pawła II, w: K. G r y z (red.), Człowiek droga Kościoła. Moralne aspekty nauczania Jana Pawła II, Kraków 2004, s. 493-506. 
Przypomniał, że w obrzędach Mszy św. wiele elementów zwraca uwagę na wymóg oczyszczenia i nawrócenia. Najpierw akt pokuty na początku liturgii, potem modlitwy o przebaczenie, znak pokoju, wreszcie modlitwy, które kapłani i wierni odmawiają przed Komuniąa ${ }^{4}$. Wskazując na nauczanie Soboru Trydenckiego, św. Jan Paweł II podkreślił, że „tylko ten, kto jest szczerze przekonany, że nie popełnił grzechu śmiertelnego, może przyjąć Ciało Chrystusa. [...] jest potrzebne, żeby nikt, będąc świadomy popełnienia ciężkiego grzechu, nawet gdyby zdawało mu się, że za niego żałuje, nie przystępował do świętej Eucharystii bez uprzedniej sakramentalnej spowiedzi"s. Jednocześnie wezwał kapłanów, by dbali o sprawowanie misterium eucharystycznego z czystym sercem i szczerą miłością, a jako wytrwali, otwarci i kompetentni szafarze sakramentu pojednania byli prawdziwym wizerunkiem świętego i miłosiernego Chrystusa ${ }^{6}$.

Benedykt XVI podczas pierwszego oficjalnego spotkania ze spowiednikami wskazał na kwestie, na których mu bardzo zależy i do których będzie wracał przy kolejnych okazjach. Oprócz nieustannego podkreślania znaczenia tego sakramentu dla duchowego i moralnego wzrostu uczniów Jezusa, będą nimi: gorliwość kapłańska w sprawowaniu sakramentu pokuty i pojednania; konieczność permanentnej formacji teologicznej, pastoralnej i pedagogicznej oraz pogłębiania życia duchowego spowiedników; troska, by spowiedź była dla penitentów głęboko odczuwanym doświadczeniem spotkania z miłosiernym Bogiem. W spotkaniu tym, które obiektywnie uobecnia „odkupieńczą skuteczność paschalnego Misterium Chrystusa [...] spowiednik staje się świadomym pośrednikiem we wspaniałym działaniu łaski. [...] szafarzem niosącego pociechę Bożego miłosierdzia,

${ }^{4} \mathrm{Na}$ ten istotny związek Benedykt XVI w podobny sposób zwrócił uwagę w posynodalnej adhortacji apostolskiej Sacramentum caritatis, por. nr 20-21.

5 J a n P a w eł II, Przesł. Eucharystia i sakrament pojednania (Rzym-Poliklinika Gemelli, 8.03.2005), „L'Osservatore Romano” wyd. pol. 26 (2005) nr 5, s. 47; por. Sobór Trydencki, Sesja XIII rozdz. 7, Denzinger 1646-1647; Katechizm Kościoła Katolickiego, nr 1385; J a n P a w eł II, Encyklika Ecclesia de Eucharistia, nr 36-37.

${ }^{6}$ Por. Ja n P a w $\nmid$ II, Przesł. Eucharystia i sakrament pojednania, art. cyt., s. 47. 
odsłania rzeczywistość grzechu, a jednocześnie ukazuje niezmierną odnawiającą moc miłości Bożej - miłości przywracającej życie"7. Kapłan nie jest biernym obserwatorem, lecz persona dramatis, czyli czynnym narzędziem łaski Bożego miłosierdzia, które objawia się przez jego słowa i gesty. „Doznając czułości i przebaczenia Pana, penitent łatwiej skłania się do uznania powagi grzechu, bardziej zdecydowanie postanawia go unikać oraz trwać i wzrastać w odzyskanej przyjaźni z Bogiem".

Do myśli tych Papież powrócił w przemówieniu do uczestników kursu dla spowiedników. Podkreślił, że zadaniem spowiednika, które wypełnia on in persona Christi, jest pomóc człowiekowi doświadczyć miłości Chrystusa na drodze własnego życia, tak jak doświadczył jej św. Paweł na drodze do Damaszku. Po spotkaniu z Chrystusem, które odmieniło jego życie, Apostoł powiedział ze wzruszeniem: „umiłował mnie i samego siebie wydał za mnie” (Ga 2,20). Sakrament spowiedzi jest dla chrześcijanina taką właśnie drogą do Damaszku i podobnym doświadczeniem mysterium pietatis - odkrywania miłosiernego serca Boga i radości pojednania z Nim. W świetle Ewangelii zachęcał, by szafarz sakramentu ukazywał „miłosierną miłość Boga w słowach i sposobie, w jaki odnosi się do penitenta. Niech jak ojciec z przypowieści o synu marnotrawnym przyjmuje skruszonego grzesznika, niech mu pomaga podnieść się z grzechu, niech go zachęca do poprawy, aby nigdy nie szedł na kompromis ze złem, lecz zawsze wracał na drogę doskonałości ewangelicznej. Niech piękne doświadczenie syna marnotrawnego, który znajduje w ojcu pełnię Bożego miłosierdzia, będzie doświadczeniem każdego, kto wyznaje swoje grzechy w sakramencie pojednania" 9 .

${ }^{7}$ B e n e d y k t XVI, Przem. Z gorliwościa wypetniajcie ważna postugę w konfesjonale (Watykan, 19.02.2007), „L'Osservatore Romano” wyd. pol. 28 (2007) nr 5, s. 43.

8 Tamże.

9 B e n e d y k t XVI, Przem. Kapłan jest narzędziem miłosiernej miłości Boga (Watykan, 16.03.2007), „L'Osservatore Romano” wyd. pol. 28 (2007) nr 6, s. 30; por. J a n P a w eł II, List apostolski Novo millennio ineunte (Watykan, 6.01.2001), nr 37. 
Owocne objawianie czułości i przebaczającej miłości Boga staje się możliwe wtedy, gdy najpierw spowiednik dążąc do świętości osobiście tego doświadcza. „Świadomość własnych ograniczeń oraz potrzeba uciekania się do Bożego miłosierdzia, by prosić o przebaczenie, by nawrócić serce i być wspieranym na drodze świętości, mają zasadnicze znaczenie w życiu kapłana: jedynie ten, kto wcześniej sam doświadczył ich wielkości, może być przekonanym zwiastunem i szafarzem Bożego miłosierdzia"10. Jego własne doświadczenie stanie się motorem starań, aby także penitenci doświadczali Bożej czułości wobec skruszonych grzeszników, tak jak doświadczali tego bohaterowie Ewangelii. Benedykt XVI daje przykład odwoływania się do Ewangelii, np. analizując opisaną przez św. Łukasza znaną scenę spotkania Jezusa z prostytutką w domu Szymona (por. Łk 7, 36-50)

Godny zauważenia jest bardzo prosty i bezpośredni sposób przypomnienia tego ewangelicznego wydarzenia oraz wymownego przesłania, że temu kto bardzo miłuje, Bóg wszystko przebacza. Natomiast temu, kto polega na samym sobie i na własnych zasługach, grozi zaślepienie w grzechu i zatwardziałość serca. Dlatego Benedykt XVI zachęca spowiedników, by gorliwie przekazywali przesłanie, że kto uznaje, iż jest słaby i grzeszny oraz powierza się Bogu, ten od Niego otrzymuje łaskę i przebaczenie. „To, co liczy się najbardziej, to pomóc zrozumieć, że w sakramencie pojednania, niezależnie od tego, jaki grzech człowiek popełnił, jeśli uznaje go pokornie i pełen ufności udaje się do kapłana spowiednika, doświadcza zawsze przynoszącej ukojenie radości z przebaczenia Bożego"12.

10 B e n e dy k t XVI, Przem. «Kryzys» sakramentu pokuty jest wyzwaniem przede wszystkim dla kapłanów (Watykan, 11.03.2010), „L'Osservatore Romano” wyd. pol. 31 (2010) nr 5, s. 34.

${ }^{11}$ Por. B e n e d y k t XVI, Przem. Bierzcie przykład z tak wielu świętych spowiedników (Watykan, 7.03.2008), „L'Osservatore Romano” wyd. pol. 29 (2008) nr 4, s. 34.

12 Tamże. O należnym miejscu Pisma Świętego i jego roli w sprawowaniu sakramentu pokuty Papież przypomniał w adhoratacji apostolskiej Verbum Domini (Watykan, 30.09.2010), por. nr 61. 
Interesującym wątkiem papieskiego nauczania jest podkreślenie waloru pedagogicznego sakramentu pokuty, i to nie tylko dla penitentów, ale najpierw dla samych kapłanów. To dla nich konfesjonał może stać się prawdziwym miejscem uświęcenia, gdy na wzór wielkich świętych, takich jak św. Jan Maria Vianney, św. Jan Bosko, św. Josemaria Escriva, św. Pio z Pietrelciny, św. Józef Cafassa i św. Leopold Mandicia, będą okazywać wierną i wielkoduszną gotowość do słuchania spowiedzi. Odpowiadając na pytanie, w jaki sposób sakrament pokuty wychowuje kapłana, Benedykt XVI określa misję kapłańską mianem jedynego i szczególnie dogodnego „punktu obserwacyjnego", który pozwala na co dzień kontemplować wielkość Bożego miłosierdzia. Podczas sprawowania sakramentu pokuty kapłan jest wielokrotnie świadkiem prawdziwych cudów nawrócenia, które umacniają jego wiarę. W istocie są to każdorazowo professiones fidei, w których szafarz sakramentu może kontemplować działanie Bożego miłosierdzia w historii, i jako świadek patrzeć z bliska na zbawcze skutki krzyża i zmartwychwstania Chrystusa w życiu swoich penitentów ${ }^{13}$.

Spowiednik nierzadko staje w obliczu prawdziwych dramatów egzystencjalnych i duchowych, wobec których trudno znaleźć odpowiednie słowa wyjaśnienia lub jakiejś podpowiedzi. Wszystko to jednak ogarnia i przyjmuje Boża Miłość, która przebacza i przemienia: „Choćby wasze grzechy były jak szkarłat, jak śnieg wybieleją” (Iz 1, 18). „Poznawanie i w pewnym stopniu nawiedzanie otchłani serca człowieka, także jego mrocznych aspektów, choć z jednej strony wystawia na próbę człowieczeństwo i wiarę samego kapłana, z drugiej umacnia w nim pewność, że w kwestii zła w człowieku i historii ostatnie słowo należy do Boga, należy do Jego Miłosierdzia, które potrafi wszystko czynić nowe (por. Ap 21, 5)"’14. W szczególności kapłan może się wiele nauczyć od penitentów, którzy prowadzą

13 Por. B e n e dy k t XVI, Przem. W kwestii zła w człowieku i historii ostatnie słowo należy do Boga (Watykan, 25.03.2011), „L'Osservatore Romano” wyd. pol. 32 (2011) nr 5, s. 24.

14 Tamże. 
przykładne życie duchowe, rzetelnie robią rachunek sumienia, szczerze i odważnie uznają własny grzech i są posłuszni nauczaniu Kościoła oraz wskazaniom spowiednika. Spotkania z takimi penitentami stają się dla kapłana głęboką lekcją pokory i wiary oraz pobudzają świadomość jego kapłańskiej tożsamości. „Gdybyśmy liczyli tylko na nasze człowieczeństwo, absolutnie nie moglibyśmy słuchać spowiedzi braci! Jeżeli do nas przychodzą, to tylko dlatego, że jesteśmy kapłanami na wzór Chrystusa, Najwyższego i Wiecznego Kapłana, i dana nam została moc działania w Jego imieniu i w Jego osobie, rzeczywistego uobecniania Boga, który przebacza, odnawia i przemienia. Sprawowanie sakramentu pokuty ma dla kapłana walor pedagogiczny w odniesieniu do jego wiary, prawdy i ubóstwa jego osoby i pogłębia w nim świadomość tożsamości sakramentalnej”'15.

Jednocześnie papież zwraca uwagę na naturalny fundament sakramentalnego spotkania jakim jest życzliwe przyjęcie i cierpliwe wysłuchanie penitenta. W czasach, w których dominuje zgiełk, rozkojarzenie i samotność, rozmowa ze spowiednikiem jest być może jedną z nielicznych, jeśli nie jedyną okazją dla penitenta, aby ktoś naprawdę i do końca go wysłuchał. Stąd papieski apel: „Drodzy kapłani, pamiętajcie, by poświęcać należną uwagę pełnieniu posługi spowiedzi w konfesjonale: akceptacja i wysłuchanie drugiego są również ludzkim znakiem otwartości i dobroci Boga dla Jego dzieci"'16. Słowa te są przykładem, że papież mocno akcentuje osobiste świadectwo i postawę spowiednika, które są tak samo potrzebne, jak wypowiadane przez niego słowa, a niekiedy oddziałują nawet bardziej niż one.

W ten sposób kapłan-spowiednik reprezentuje i naśladuje Chrystusa, dla którego głoszenie dobrej nowiny o przebaczeniu nie oznacza tylko słów, ale objawia się także w konkretnych gestach ludzkiej dobroci, życzliwości i czułości wobec grzeszników ${ }^{17}$. „Jakże

\footnotetext{
15 Tamże.

16 Tamże.

${ }_{17}$ Por. B e n e d y k t XVI, Kat. Kapłani darem dla Kościoła i świata (Watykan, 5.05.2010), „L'Osservatore Romano” wyd. pol. 31 (2010) nr 7, s. 50.
} 
nadzwyczajną posługę powierzył nam Pan! Podobnie jak w czasie sprawowania Eucharystii oddaje się On w ręce kapłana, by nadal być obecnym pośród swego ludu, tak powierza się On kapłanowi w sakramencie pojednania, aby ludzie doświadczyli uścisku, z jakim ojciec przyjmuje na nowo syna marnotrawnego, przywracając mu synowską godność i czyniąc go ponownie i w pełni dziedzicem (por. Łk 15, 11-32)"18.

Wielokrotne doświadczanie Bożego miłosierdzia poprzez słowa i gesty spowiednika umacnia wiarę penitenta i staje się jedną z niezastąpionych dróg nowej ewangelizacji ${ }^{19}$. Benedykt XVI stwierdza nawet, że nowa ewangelizacja rozpoczyna się od konfesjonału, pod warunkiem, że penitent będzie tam doświadczał miłosierdzia, którym obdarzał człowieka Jezus z Nazaretu ${ }^{20}$. Stąd papieski apel o wrażliwość i gorliwość kapłanów: „Drodzy współbracia, trzeba powrócić do konfesjonału jako miejsca sprawowania sakramentu pojednania, ale także jako miejsca, w którym należy »przebywać« częściej, aby wierny mógł znaleźć miłosierdzie, radę i umocnienie, mógł poczuć

18 B e n e dy k t XVI, Przem. «Kryzys» sakramentu pokuty jest wyzwaniem przede wszystkim dla kapłanów, dz. cyt., s. 34.

19 Por. K. J e ż y n a, Sakrament pokuty źródłem nowej ewangelizacji, ,Roczniki Teologiczne", 53(2006) z. 3, s. 25-38.

20 Por. B e n e d y k t XVI, Przem. Spowiedź sakramentalna siła nowej ewangelizacji (Watykan, 9.03.2012), „L'Osservatore Romano” wyd. pol. 33 (2012) nr 5, s. 48. „Szafarz sakramentu pojednania współpracuje w nowej ewangelizacji, gdy jako pierwszy odnawia w sobie świadomość, że sam jest penitentem i potrzebuje uzyskać sakramentalne przebaczenie, ażeby doszło do odnowy tego spotkania z Chrystusem, które rozpoczęło się chrzcie, a znalazło swój ostateczny kształt w sakramencie kapłaństwa. Takie jest moje życzenie dla każdego z was: aby nowość Chrystusa była zawsze najważniejszym celem i racją waszego kapłańskiego życia, ażeby ludzie, którzy was spotkają, mogli - za sprawą waszej posługi - głosić jak Andrzej i Jan: «Znaleźliśmy Mesjasza» (J 1, 41). W ten sposób każda spowiedź, po której chrześcijanin wyjdzie odnowiony, będzie stanowić krok naprzód w nowej ewangelizacji” (Tamże). 
się kochany i zrozumiany przez Boga oraz doświadczyć obecności Bożego miłosierdzia obok rzeczywistej Obecności w Eucharystii”’1.

\section{ROK KAPLAŃSKI}

Szczególną okazją, by wyrazić troskę o owocne sprawowanie sakramentu pokuty i pojednania, a także o kapłana jako szafarza sakramentu był Rok Kapłański, ogłoszony z okazji 150. rocznicy narodzin dla nieba św. Jana Marii Vianneya. Postać świętego Proboszcza z Ars nieodmiennie kojarzy się z heroiczną i niezwykle owocną posługą pojednania, co znalazło swój wyraz w papieskich wypowiedziach skierowanych do kapłanów jako spowiedników. Już w liście na rozpoczęcie Roku Kapłańskiego Benedykt XVI napisał: „my wszyscy, kapłani, powinniśmy odczuwać, że bezpośrednio dotyczą nas słowa, które on [Proboszcz z Ars] wkładał w usta Chrystusa: »Polecę moim szafarzom, żeby głosili grzesznikom, że jestem gotów zawsze ich przyjąć, że moje miłosierdzie jest nieskończone«. Od Świętego Proboszcza z Ars my, kapłani, możemy uczyć się nie tylko niewyczerpanej ufności w Sakrament Pokuty, która sprawia, że staje się on głównym przedmiotem naszej troski duszpasterskiej, lecz także metod »dialogu zbawienia«, który powinien w nim się toczyć" 22 .

Należy podkreślić, że cały list stanowi syntetyczne przypomnienie pedagogii pokuty i pojednania, którą owocnie stosował św. Jan Maria Vianney. Do jej istotnych elementów należy osobisty przykład kapłana, który jako pierwszy doświadcza Bożego miłosierdzia, ofiarnie szuka zagubionych owiec i pokutuje za grzeszników, okazując im łagodność, m.in. poprzez zadawanie niewielkiej pokuty, której dopełnienie spowiednik bierze na siebie. Papież Benedykt XVI wydobył z nauczania świętego Proboszcza z Ars ciągle aktualne

${ }^{21}$ B e n e d y k t XVI, Przem. «Kryzys» sakramentu pokuty jest wyzwaniem przede wszystkim dla kapłanów, dz. cyt., s. 34.

${ }^{22}$ B e n e d y k t XVI, List na rozpoczęcie Roku Kapłańskiego z okazji 150. rocznicy «dies natalis» Świętego Proboszcza z Ars (Watykan, 16.06.2009), „L'Osservatore Romano" wyd. pol. 30 (2009) nr 7-8, s. 5. 
wskazania przydatne spowiednikom i ich penitentom, których trzeba każdorazowo traktować w indywidualny sposób. Dla przykładu, tych zgnębionych świadomością własnej słabości i niestałości oraz lękających się przyszłych grzechów można zapewnić wzruszającymi i pięknymi słowami świętego: „Dobry Bóg zna wszystko. Jeszcze zanim się wyspowiadacie, już wie, że będziecie nadal grzeszyć, a mimo wszystko wam przebacza. Jakże wielka jest miłość naszego Boga, która posuwa się aż do chęci zapomnienia o przyszłości, żeby nam przebaczyć!"’23.

Podczas nieszporów z Uroczystości Najświętszego Serca Pana Jezusa na rozpoczęcie Roku Kapłańskiego Benedykt zwrócił uwagę na słynne stwierdzenie św. Jana Marii Vianneya - przypomniane przez Katechizm Kościoła Katolickiego - że „Kapłaństwo - to miłość Serca Jezusowego"24. Papież podkreślił, że Pan Jezus staje się Sercem ludzkich serc, zaczynając od kapłanów, którzy są powołani, by być bliżej Niego. Dlatego nie powinni się nigdy oddalać od źródła Miłości, którym jest Serce Jezusa przebite na krzyżu. Wprawdzie kapłani zobowiązują się do tego w dniu święceń i odnawiają swoje przyrzeczenia kapłańskie każdego roku w Wielki Czwartek, ale w swoim dążeniu do świętości nie przestają być słabymi i grzesznymi ludźmi. „Także nasze braki, nasze ograniczenia i słabości winny prowadzić nas do Serca Jezusa. Jeżeli bowiem prawdą jest, że grzesznicy, kontemplując Go, winni uczyć się od Niego »żalu za grzechy«, który ma ich doprowadzić do Ojca, tym bardziej odnosi się to do wyświęconych szafarzy"25.

Papieskiemu wezwaniu do nadziei towarzyszyło bardzo jasne przypomnienie o wielkiej odpowiedzialności kapłanów, gdyż „nic nie zadaje tak wielkiego cierpienia Kościołowi, Ciału Chrystusa, jak grzechy jego pasterzy, zwłaszcza tych, którzy zamieniają się

23 Tamże.

${ }^{24}$ B e ne dy k t XVI, Hom. Tajemnica miłości Boga do ludzi (Watykan, 19.06.2009), „L'Osservatore Romano” wyd. pol. 30 (2009) nr 9, s. 37; Katechizm Kościoła Katolickiego, nr 1589.

${ }^{25}$ B e n e d y k t XVI, Hom. Tajemnica miłości Boga do ludzi, dz. cyt., s 37. 
w »złodziei owiec« (por. J 10,1nn). [...] Wezwanie do nawrócenia i do uciekania się do Bożego Miłosierdzia skierowane jest także do nas, drodzy kapłani; powinniśmy też zwracać się z pokorną, żarliwą i nieustającą prośbą do Serca Jezusa, aby nas zachowało od wielkiego niebezpieczeństwa - szkodzenia tym, których mamy obowiązek zbawiać" 26 .

Przy okazji liturgicznego wspomnienia św. Jana Marii Vianneya, Benedykt XVI po raz kolejny podkreślił cechy, które mogą posłużyć jako wzór dla współczesnych kapłanów. Nawiązując do listu na rozpoczęcie Roku Kapłańskiego wskazał na gorliwą posługę spowiedzi jako zasadniczą cechę, która wyróżniała tego nadzwyczajnego kapłana. „Praktykę sakramentu pokuty uznawał [on] za logiczne i naturalne wypełnianie kapłańskiego apostolstwa, w posłuszeństwie poleceniu Chrystusa: »Którym odpuścicie grzechy, są im odpuszczone, a którym zatrzymacie, są im zatrzymane« (J 20, 23). Św. Proboszcz z Ars wyróżniał się przeto jako znakomity i niezmordowany spowiednik i mistrz duchowy. Prowadzony $» j$ jednym poruszeniem wewnętrznym - od ołtarza do konfesjonału«, gdzie spędzał znaczną część dnia, "starał się na wszelkie sposoby, przez kaznodziejstwo i skuteczną radę, umożliwić swoim parafianom odkrycie znaczenia i piękna sakramentalnej pokuty, ukazując ją jako wewnętrzny wymóg Obecności eucharystycznej«"27. Można więc powiedzieć, że wypowiedzi papieża bezpośrednio odwołujące się do nauk św. Jana Marii Vianneya stanowią wskazanie, by czynić podobnie sięgając do źródła ${ }^{28}$.

26 Tamże.

${ }^{27}$ B e n e d y k t XVI, Kat. Św. Jan Maria Vianney (Castel Gandolfo, 5.08.2009), „L'Osservatore Romano” wyd. pol. 30 (2009) nr 10, s. 30.

28 Wśród publikacji w języku polskim warto wskazać na Kazania proboszcza z Ars. Wybór homilii niedzielnych i świątecznych św. Jana Marii Vianney, Patrona Kapłanów, wyd. 5, Warszawa 2009 (publikacja zawiera m.in. 9 kazań poświęconych sakramentowi pokuty); Św. A 1 fons Maria de Ligu ori, Praktyczny przewodnik dla spowiednika. Aby dobrze sprawowat swoja posługe,(tłum. K. Stopa), Kraków 2010. 
Rok Kaptański był okazją, by zwrócić uwagę także na innego świętego spowiednika, ojca Pio i wskazać go jako wzór dla współczesnych kapłanów. Podczas wizyty w San Giovanii Rotondo Benedykt XVI podkreślił, że najgłębszym motywem jego zaangażowania w posługę spowiedniczą - podobnie jak w przypadku św. Jana Marii Vianneya - było umiłowanie Eucharystii. Pragnienie, by otworzyć wiernym drogę do jej pełnego i owocnego przeżywania trawiło św. ojca Pio aż do śmierci. Zachęcając do naśladowania świętego kapucyna papież wskazywał na wyróżniającą go posługę spowiednika: „Ileż osób odmieniło swoje życie dzięki jego cierpliwej posłudze kapłańskiej; ileż długich godzin spędzał on w konfesjonale! [...] Czyż można zatem nie zdawać sobie sprawy z tego, jak ważne jest pobożne uczestniczenie w Eucharystii i częste przystępowanie do sakramentu spowiedzi? W szczególności sakrament pokuty winien być bardziej doceniany, a kapłani nie powinni nigdy pogodzić się z tym, że nikt nie przychodzi do konfesjonału, czy ograniczać się do stwierdzenia, że wierni zniechęcili się do tego nadzwyczajnego źródła spokoju ducha i pokoju”29.

Wskazując na osobę św. o. Pio jako wzór dla spowiedników warto pamiętać, że musiał on pokonać ogromne trudności, by otrzymać władzę spowiadania i potem przez ponad pięćdziesiąt lat tak owocnie spełniać tę posługę. Wobec kwestionowania jego teologicznych kompetencji i podkreślania jego słabego zdrowia, zachował postawę twórczego posłuszeństwa. Pokornie przyjmuje wolę przełożonych, ale nie przestaje nalegać o udzielenie władzy spowiadania. Skłania go do tego nade wszystko miłość do bliźnich i tajemniczy wewnętrzny głos, którego nie mógł zagłuszyć. Owoce jego kapłańskiego życia wyraźnie potwierdzają, że był to głos szczególnego Bożego powołania do sprawowania sakramentu pokuty ${ }^{30}$.

29 B e n e d y k t XVI, Przem. Bądźcie wiernymi przyjaciółmi Jezusa jak Ojciec Pio (San Giovanni Rotondo, 21.06.2009), „L'Osservatore Romano” wyd. pol. 30 (2009) nr 10, s. 15.

${ }^{30}$ Por. T. D a C e r vi n a r a, Ojciec Pio - spowiednik. Nadzwyczajny $i$ wyjątkowy ożywiciel „,martwych dusz”, w: Ojciec Pio. Heroiczny spowiednik, (łum. 
Warto zwrócić uwagę także na społeczny, wręcz globalny, wątek papieskiej refleksji nad znaczeniem kapłańskiej posługi sakramentalnego jednania człowieka z Bogiem. Benedykt XVI przypomniał, że pojednanie jest konieczne, by zapanował pokój społeczny. Dlatego jest ono potrzebne dobrej polityce, ale ona sama nie jest w stanie urzeczywistnić pojednania. W istocie bowiem chodzi o procesy, które poprzedzają politykę i biorą początek z innych źródeł. Samo pojęcie i rzeczywistość pojednania jest starsza niż polityka i właśnie dlatego wpisuje się w jej podstawowe zadania. Jednak politycznemu zaangażowaniu na rzecz pokoju i pojednania zabraknie wewnętrznej podstawy, jeśli siła pojednania nie zrodzi się w ludzkich sercach przekonanych o potrzebie wewnętrznego oczyszczenia i dojrzewania do pełni człowieczeństwa. Ten wstępny warunek budowania sprawiedliwości i pokoju - jak podkreśla Papież - nie jest jednak możliwy bez Boga ${ }^{31}$.

Ojciec św. zwraca uwagę, że to sam Bóg ukazuje nam drogę do pojednania, a jednocześnie daje łaskę - umożliwia pójście tą drogą. Jest to droga bezinteresowności i wielkoduszności, która przejawia się w gotowości czynienia więcej niż nakazuje konieczność lub zwykła sprawiedliwość, w gotowości uczynienia pierwszego kroku. Jej przykład daje Bóg, który wychodzi naprzeciw człowieka aż po Krzyż Jezusa. Dlatego naśladując Boga i biorąc od Niego siłę „musimy pierwsi wychodzić naprzeciw drugiemu, prosić o pojednanie, godzić się na cierpienie, jakim jest rezygnacja ze swojej racji. Nie słabnąć w chęci pojednania. [...] Powinniśmy na nowo nabyć zdolności do uznania własnej winy, powinniśmy uwolnić się od złudzenia niewinności. Powinniśmy nabyć zdolności czynienia pokuty, godzenia się na przemianę, wychodzenia naprzeciw drugiemu człowiekowi oraz

S. Kafel), Kraków 2002, s. 9-15.

${ }^{31}$ Por. B e n e d y k t XVI, Przem. Jesteśmy przyjaciólmi tych, którzy znaja Boga, i tych, którzy Go jeszcze nie znaja (Watykan, 21.12.2009), „L'Osservatore Romano" wyd. pol. 31 (2010) nr 2, s. 39-40. 
proszenia Boga o dar odwagi i siły do odnowy. W naszym dzisiejszym świecie powinniśmy odkryć sakrament pokuty i pojednania"32.

Prezentując wskazania, które Benedykt XVI kierował przede wszystkim do szafarzy sakramentu, należy zauważyć, że odnoszą się one także do kandydatów do kapłaństwa. Przy różnych okazjach podczas spotkań z seminarzystami, papież - podobnie jak czynił to św. Jan Paweł II - podkreślał znaczenie spowiedzi w ramach formacji oraz potrzebę dobrego przygotowania się do przyszłej posługi ${ }^{33}$. Najważniejsze myśli przypomniał w Liście do seminarzystów, w którym po raz kolejny przywołał nauczanie św. Jana Marii Vianney'a. „Również sakrament pokuty jest ważny. Uczy mnie patrzeć na siebie z Bożego punktu widzenia, zmusza mnie do uczciwości w stosunku do siebie. Wskazuje mi drogę do pokory. Proboszcz z Ars powiedział kiedyś: Myślicie, że nie ma sensu otrzymanie dziś rozgrzeszenia wiedząc, że jutro znów popełnicie te same grzechy. Jednak - mówi - Bóg sam zapomina w tym momencie o waszych jutrzejszych grzechach, by dać wam łaskę dziś. Chociaż musimy nieustannie walczyć z tymi samymi błędami, ważne jest przeciwstawianie się zeszpeceniu duszy, obojętności, która godzi się z tym, że tacy już jesteśmy. Ważne jest, by wciąż być w drodze, bez zbędnej skrupulatności, z pełną wdzięczności świadomością, że Bóg wciąż na nowo mi przebacza, ale i bez obojętności, która nie pozwoliłaby walczyć o świętość i o poprawę. A dając sobie przebaczyć, uczę się także przebaczać innym. Uznając, że jestem nędzny, staję się bardziej tolerancyjny i wyrozumiały dla słabości bliźniego"34

32 Tamże, s. 39.

${ }^{33} \mathrm{~W}$ adhortacji apostolskiej Pastores dabo vobis Jan Paweł II podkreślił, że „bardzo konieczny i pilny jest postulat ponownego odkrycia, podczas formacji duchowej, piękna i radości sakramentu pokuty" (nr 48). Por. R. S e le j d a k, Znaczenie sakramentu pokuty $w \dot{z} y c i u$ i posłudze kapłana oraz $w$ formacji seminarzystów, „Warszawskie Studia Teologiczne”, 25(2012) nr 2, s. 206-209.

${ }^{34}$ B e n e d y k t XVI, List do seminarzystów (Watykan, 18.10.2010), „L'Osservatore Romano" 31 (2010) nr 11, s. 5. 


\section{DOKUMENT O POSŁUDZE SPOWIEDNIKÓW}

Szczególnym wyrazem troski o kapłanów jako szafarzy sakramentu pokuty i pojednania oraz kierowników duchowych jest dokument Kongregacji ds. Duchowieństwa Kapłan - szafarz miłosierdzia Bożego, wydany w Watykanie 9 marca 2011 roku $^{35}$. Owszem, każdy ze spowiedników mógłby systematycznie sięgać do wcześniej omawianych wypowiedzi lub do jakiegoś ich zbioru i z korzyścią dla swojej posługi analizować te wypowiedzi. W praktyce jednak nie jest to takie proste i o wiele łatwiej jest sięgnąć do 50-cio stronicowej książeczki, stanowiącej pomoc w posłudze uświęcania na drodze sakramentalnej i kierownictwa duchowego ${ }^{36}$. Tym dwóm aspektom poświęcone są odpowiednio pierwszy rozdział dokumentu: Posługa pokuty i pojednania w perspektywie świętości chrześsijańskiej oraz drugi rozdział: Postuga kierownictwa duchowego.

Wśród podstawowych kwestii, które dokument przypomina spowiednikowi, jest paschalny charakter celebracji sakramentu pokuty i pojednania. Zmierza ona bowiem - pod przewodnictwem Ducha Świętego - do nowego spotkania z miłującym Ojcem i Dobrym Pasterzem. Jest to więc celebracja powołania do nawrócenia (por. Łk 15,18), która wiąże się z wysiłkiem odpowiedzi na miłość Bożą. Chrześcijanin wezwany do nawrócenia, które jest istotnym elementem głoszenia Królestwa Bożego, włącza się w dynamizm łaski, która porusza skruszone serce (por. Ps 51, 19) i pobudza je do odpowiedzi na miłosierną miłość Boga, który pierwszy umiłował człowieka (por. $1 \mathrm{~J} 4,10$ ). W ten sposób życie chrześcijańskie staje się wędrówką do świętości, która zanim stanie się wymaganiem,

${ }^{35}$ Kongregacja ds. Duchowieństwa, Kapłan - szafarz miłosierdzia Bożego. Pomoce dla spowiedników i kierowników duchowych (Watykan, 9.03.2011), (tłum. J. Królikowski), Tarnów 2011.

36 Taki cel publikacji został wyraźnie podkreślony we wprowadzeniu: „Niniejsze «pomoce» zamierzają dostarczyć kilku prostych, wykonalnych i budzących nadzieję przykładów, które odwołują się do licznych dokumentów kościelnych (cytowanych w różnych punktach), do których można ewentualnie sięgnąć. Nie chodzi o kazuistykę, ale o posługę budzącą nadzieję i zachętę" (nr 6). 
najpierw jest umożliwiona przez sakramenty wtajemniczenia i słowo Boże. Uznanie tej uprzedzającej łaski rodzi właśnie potrzebę wchodzenia w ewangeliczną dynamiką przebaczenia i miłosierdzia już od dzieciństwa, od czasu przygotowania do pierwszej Komunii świętej. Pomaga także zrozumieć znaczenie wyznawania grzechów lekkich i niedoskonałości dla postępu na drodze życia w Duchu ${ }^{37}$. Takie podkreślenie rzeczywistości łaski jest dzisiaj szczególnie ważne z dwóch powodów. Po pierwsze, próbuje się kwestionować potrzebę sakramentu pokuty i pojednania dzieci przed pierwszą Komunią świętą, w imię ich rzekomej bezgrzeszności i chęci uchronienia przed traumą spowiedzi ${ }^{38}$. Po drugie, nasila się zjawisko zaniku poczucia grzechu, do którego przyczynia się m.in. lekceważenie osłabiającej i destrukcyjnej mocy grzechów powszednich, których wyznawanie uznaje się za niepotrzebne ${ }^{39}$.

37 Por. Kongregacja ds. Duchowieństwa, Kapłan-szafarz miłosierdzia Bożego, dz. cyt., nr 25-35.

38 Odpowiedzią na ten fałszywy kierunek refleksji nad spowiedzią dzieci powinno być współdziałanie rodziców, katechetów i kapłanów w ukazywaniu ogromu i piękna miłości Pana Jezusa do grzeszników. Por. A. D 1 u g o s z, Moja pierwsza spowiedź, Radom 2008; M. D z i e w i c k i, Pierwsza spowiedź czyli doświadczenie miłości, „Różaniec”, (2009) nr 4, s. 24-25; M. K o n i k - K o r n, Czy dziecko może zgrzeszyć? „Niedziela”, (2012) nr 21, s. 24-25; D. M a d e j c z y k, Kiedy pierwsza spowiedź? „Przewodnik Katolicki” nr 20 (20.05.2012), s. 40-41; L. B a 1 i c k i, Po co te dyskusje o spowiedzi dzieci! „Przewodnik Katolicki”, http://www.przewodnik-katolicki.pl/ $\mathrm{pg} / \mathrm{pl} / \mathrm{komentarze} / \mathrm{ks}$ _lech_bilicki/po_co_te_dyskusje_o_spowiedzi_dzieci.html (12.05.2014).

39 W adhortacji Reconciliatio et paenitentia Jan Paweł II stwierdził, że „konieczne jest przywiązywanie w dalszym ciągu dużej wagi do korzystania z Sakramentu Pokuty także wtedy, gdy chodzi o grzechy powszednie, i wychowywanie do tego wiernych. Potwierdza to tradycja doktrynalna i wiekowa praktyka. Wiedząc i nauczając, że grzechy powszednie mogą być darowane również w inny sposób przez akt żalu, uczynki miłości, modlitwę, akty pokutne - Kościół nie przestaje przypominać wszystkim o szczególnym bogactwie zawartym w akcie sakramentalnym także w odniesieniu do tych grzechów. Częste przystępowanie do Sakramentu - do czego zobowiązane są pewne kategorie osób - wzmacnia świadomość, że również mniejsze grzechy obrażają Boga i ranią Kościół, Ciało Chrystusa, a korzystanie z Sakramentu staje się pobudką i okazją do tego, by «w doskonalszy 
W tym kontekście ważnym zadaniem spowiednika jest budzenie odpowiedniej dyspozycji penitenta. Akcent pada tu na uprzedzające działanie miłosiernego Boga, który daje penitentowi łaskę odpowiedzi na miłość poprzez sakramentalne gesty pokuty, nazywane aktami penitenta. Żal za grzechy, następnie jasne, proste i integralne wyznanie ich, wreszcie zadośćuczynienie lub wynagrodzenie za swoje złe postępowanie, jest potwierdzeniem ponownego ukierunkowania życia na wędrówkę miłości do Boga i do bliźniego. Akty te są znakiem współdziałania z Duchem miłości, który porusza i uzdalnia penitenta do odpowiedzi na łaskę przebaczenia. Ona „dotyka samego korzenia grzechu popełnionego po chrzcie oraz leczy niedoskonałości i odstępstwa, dając wierzącemu siłę do »nawrócenia się« lub otwarcia w większym stopniu na doskonałość miłości”40.

Warto w tym miejscu przypomnieć, że św. Jan Paweł II zachęcał spowiedników, by odpowiednio do sytuacji penitenta pomagali mu nie tylko w integralnym wyznaniu grzechów, ale także w pełnym ufności spojrzeniu w przyszłość i otwarciu się na dar odnowionego życia. Pierwsza sprawa wiąże się z zadawaniem stosownych pytań. „Dbając o integralność spowiedzi - nieodzowną w przypadku grzechów ciężkich - to znaczy dążąc do ustalenia ich rodzaju, okoliczności decydujących dla danego rodzaju oraz liczby grzechów, trzeba troszczyć się, aby spowiedź nie stała się praktyką odpychającą i przykrą, szczególnie dla ludzi o słabej pobożności lub wchodzących na drogę nawrócenia. Należy przy tym zawsze kłaść ogromny nacisk na potrzebę wielkiej delikatności w traktowaniu spraw związanych z szóstym przykazaniem Dekalogu" ${ }^{\prime 11}$. Z drugiej strony, potrzeba

sposób upodabniać się do Chrystusa i wierniej ulegać głosowi Ducha Świętego» (Obrzędy pokuty nr 7). Należy nade wszystko podkreślić fakt, że łaska właściwa temu obrzędowi sakramentalnemu ma wielką moc leczniczą i przyczynia się do usunięcia samych korzeni grzechu" (nr 32).

${ }^{40}$ Kongregacja ds. Duchowieństwa, Kapłan - szafarz miłosierdzia Bożego, dz. cyt., $\mathrm{nr} 38$.

${ }^{41} \mathrm{~J}$ a n P a w e 1 II, Przem. Postuga kapłańska $w$ sakramencie pojednania (Watykan, 27.03.1993), „L'Osservatore Romano” 14 (1993) nr 5-6, s. 44. Wskazania duszpasterskie zawiera 3 część Vademecum dla spowiedników (Watykan, 12.02.1997). 
cierpliwości i nie zrażania się wobec niezrozumienia penitentów, którzy na pytania spowiednika ,reagują tak jakby próbował on bezprawnie wtargnąć do sanktuarium ich sumienia'"42.

$\mathrm{Z}$ wyznaniem grzechów, a nawet $\mathrm{z}$ samym przystąpieniem do spowiedzi wiąże się trudność spowodowana świadomością własnej słabości i przewidywaniem powtórnych upadków. Niekiedy penitenci mają wątpliwość dotyczącą autentyczności ich skruchy i szczerości mocnego postanowienia poprawy. W tej sytuacji zadaniem spowiednika jest budzenie ufności i ukazywanie jej racjonalnych i nadprzyrodzonych motywów. ,Jak skrucha powinna wypływać przede wszystkim z żalu, że obraziło się Boga, tak postanowienie niepopełniania grzechów musi się opierać na Bożej łasce, której Chrystus nie odmawia nigdy człowiekowi, czyniącemu wszystko, co w jego mocy, aby postępować uczciwie. Gdybyśmy chcieli oprzeć postanowienie niegrzeszenia wyłącznie na własnych siłach, [...] to tak jakbyśmy mówili Bogu - bardziej lub mniej świadomie - że już Go nie potrzebujemy"43. Dlatego czym innym jest szczere postanowienie penitenta towarzyszące wyznaniu grzechów, a czym innym jego rozumowy osąd dotyczący przyszłości. Towarzyszące mu obawy nie przekreślają autentyczności jego postanowienia, ,jeśli tylko z lękiem tym łączy się wola, wspomagana modlitwą, by uczynić wszystko co możliwe w celu uniknięcia grzechu" ${ }^{\prime 44}$.

Ufnemu spojrzeniu w przyszłość i otwarciu się na dar odnowionego życia ma pomóc pokuta nadawana przez spowiednika. Obok

Por. E. B o g u r a d, B. B a s s a, K. W ols k i (red.), Posługa spowiedników w realizacji powołania malżeńskiego, Łomianki 1999.

42 J a n P a w eł II, Przesł. Sakrament pokuty wielkim darem Bożego miłosierdzia (Watykan, 22.03.1996), „L’Osservatore Romano” wyd. pol. 17 (1996) nr 6, s. 12.

43 Tamże.

44 Tamże. Właściwą postawę wobec przyszłości, która rodzi się dzięki współdziałaniu bojaźni i nadziei jasno opisał Sobór Trydencki: „Kiedy ludzie, uważając się za grzeszników, przechodzą od bojaźni przed sprawiedliwością Boga, która nimi zbawiennie wstrząsa, do rozważania miłosierdzia Bożego, wzrastają w nadziei, ufając, że Bóg, ze względu na Chrystusa, będzie im łaskawy”. Sesja VI rozdz. 6, Denzinger-Schönmetzer nr 1526. 
kryterium właściwej proporcji, powinna ona nade wszystko przeciwdziałać wyznanym przez penitenta grzechom. W formie modlitwy będzie wyrażać chwałę miłosiernego Boga i pogardę dla grzechu, który Go obraził. Będzie także wyznaniem popełnionego zła, uznaniem słabości, oraz pokorną prośbą o nadprzyrodzoną Bożą pomoc w dalszym dobrym życiu. Dlatego Jan Paweł II przypomina spowiednikom, by zadając taką pokutę uwzględniali stopień pobożności penitenta, jego kulturę duchową, zdolność rozumienia i skupienia uwagi oraz ewentualną skłonność do skrupulanctwa. Ponadto, zachęcając penitentów do modlitwy, powinni przestrzegać zasady, że lepsza jest pokuta umiarkowana, ale odprawiona żarliwie, niż bardzo uciążliwa i dlatego odprawiona z niechęcią lub nie odprawiona w ogóle. Natomiast inne czyny pokutne powinny służyć penitentowi w pracy nad sobą poprzez rozwijanie cnót. W ich nadawaniu przydatna jest zasada contra agere, która wskazuje, by leczyć zło jego przeciwieństwem. Ewangelicznym przykładem podjęcia takiej pokuty w odpowiedzi na Boże miłosierdzie jest postawa Zacheusza: „Panie, oto połowę mego majątku daję ubogim, a jeśli kogo w czym skrzywdziłem, zwracam poczwórnie" (Łk 19,8) ${ }^{45}$.

Kolejnym wskazaniem dokumentu jest potrzeba służebnej dyspozycyjności i ojcowskiego przyjęcia. Potwierdzeniem autentyczności tych postaw jest przede wszystkim modlitwa i pokuta za penitentów. Natomiast ich praktycznym przejawem będzie stworzenie takich warunków, by wierni mogli spowiadać się wtedy, gdy w sposób uzasadniony o to proszą oraz $\mathrm{w}$ ustalonych i dogodnych dla nich dniach i godzinach. Dokument przypomina zalecenia zawarte w liście apostolskim Jana Pawła II Misericordia Dei, aby spowiednicy byli obecni, widoczni i gotowi do wyjścia naprzeciw potrzebom wiernych

45 Por. J a n P a w eł II, Przem. Rola kapłana w sakramencie pokuty (Watykan, 18.03.1995), „L'Osservatore Romano” wyd. pol. 16 (1995) nr 5, s. 16. Jest to tym bardziej potrzebne, im poważniej zostało przez grzech naruszone jakieś podstawowe dobro. Przykładem może tu być działalność w obronie życia i pomoc rodzinie, jako pokuta za zbrodnię przerwania ciąży oraz hojna działalność charytatywna, przewyższająca miarę wyrządzonych szkód, jako pokuta za kradzież, oczywiście po spełnieniu obowiązku zwrotu przywłaszczonego mienia. (Por. tamże.) 
także podczas celebracji Mszy świętych. W tym celu niektórzy kapłani powinni powstrzymać się od koncelebrowania, aby być do dyspozycji wiernych ${ }^{46}$. Tym pozytywnym wskazaniom towarzyszy zdecydowane napomnienie, że „brak gotowości przyjęcia zranionych owiec, co więcej, wychodzenia im naprzeciw, aby na nowo przyprowadzić je do owczarni, byłby bolesnym znakiem zaniku świadomości duszpasterskiej u tego, kto na mocy święceń kapłańskich winien odzwierciedlać w sobie postać Dobrego Pasterza" ${ }^{\text {"47 }}$. A jego dopełnieniem jest wskazanie - po raz kolejny - na świetlany przykład spowiednika jakim jest św. Jan Maria Vianney ${ }^{48}$.

Ostatnią praktyczną kwestią jest zwrócenie uwagi na nowe sytuacje i potrzebę odnowionej gorliwości szafarzy. Będzie się ona przejawiać w ich permanentnej formacji, w szczególności w przygotowaniu teologicznym i psychologicznym. Domaga się tego nieustanny rozwój w różnych dziedzinach życia, który przynosi także nowe problemy etyczne, wobec których staje sumienie współczesnego człowieka. Sa wśród nich żywo dyskutowane kwestie bioetyczne, dotyczące m. in. sztucznego zapłodnienia. Stąd konieczność dobrej znajomości moralnego nauczania Kościoła oraz wiernego przedstawiania go penitentom - jak podkreślał św. Jan Paweł II - „bez ideologicznych zniekształceń i samowolnych uproszczeń"49. Pozwoli to uniknąć

46 Por. Kongregacja ds. Duchowieństwa, Kapłan-szafarz miłosierdzia Bożego, nr 51-56; J a n P a w e ł II, List apostolski Misericordia Dei (Watykan, 7.04.2002), nr 2; Kongregacja ds. Kultu Bożego, Odpowiedź Quaenam sunt dispositiones odnośnie do norm dotyczących czasu sprawowania sakramentu pokuty (31.07.2001), „Notitiae” 37 (2001), s. 259-260.

47 J a n P a w e 1 II, List apostolski Misericordia Dei, nr 1.

48 Por. Kongregacja ds. Duchowieństwa, Kapłan-szafarz miłosierdzia Bożego, nr 57-58.

49 J a n P a w eł II. Przem. O godne i owocne sprawowanie sakramentu pokuty (Watykan, 28.03.2003), „L'Osservatore Romano” wyd. pol. 24 (2003) nr 6, s. 38. Wiele nowych kwestii bioetycznych, przedstawionych w oficjalnych wypowiedziach Kościoła, ciągle domaga się przełożenia na praktyczny język posługi spowiedniczej. Dlatego należy zauważyć i docenić wysiłki teologów podejmowane w tym celu. Por. K. G r y z, Rozgrzeszenie po zabiegu in vitro. Głos w dyskusji, „Teologia i Moralność", (2010) nr 2, s. 25-36; D. B r y 1, Zapłodnienie in vitro w kontekście 
zamętu w sumieniach wiernych, który powstaje w wyniku rozbieżności poglądów przekazywanych przez kapłanów i prowadzi do osłabienia lub niemal zaniku prawdziwego poczucia grzechu, przed czym papież wyraźnie przestrzegał $\mathrm{w}$ adhortacji Reconciliatio et paenitentia ${ }^{50}$. „Nie można mylić miłości z odchodzeniem od prawdy $w$ imię źle rozumianej wyrozumiatości. Nie wolno nam redukować prawdy według własnego osądu, nawet w najlepszych intencjach. Naszym zadaniem jest być świadkami Boga, przekazicielami miłosierdzia, które zbawia również, gdy jawi się jako osąd nad ludzkim grzechem. »Nie każdy, który Mi mówi: Panie, Panie!, wejdzie do królestwa niebieskiego, lecz ten, kto spełnia wolę mojego Ojca, który jest w niebie « (Mt 7, 21)"'51.

Tak rozumiana posługa miłosierdzia, w której spowiednik stara się naśladować ukazany w Ewangeliach stosunek Pana Jezusa do grzeszników (por. Łk 7, 36-50; 15, 15-32; J 8, 3-11), wymaga od niego także dobrego przygotowania psychologicznego. Dotyczy to zarówno częstych sytuacji, w których „psychologiczny talent spowiednika” może pomóc w spowiedzi penitentów nieśmiałych, wstydliwych czy małomównych ${ }^{52}$, jak i szczególnych przypadków. Wśród nich jest konieczność odróżnienia zaburzeń natury psychicznej od różnych form

sakramentu pojednania i pokuty, „Teologia i Moralność”, (2011) nr 2, s. 69-90; B. W ó j c i k, Biomedycyna i konfesjonat, w: J. Augustyn (red.), Sztuka spowiadania, dz. cyt., s. 123-136; J. J. P a wło w i c z, Spowiedź osób zwiąanych ze sztucznym zapłodnieniem ,in vitro”, „Poradnik Spowiednika” grudzień 2013, s. 7-33; Forum Bioetyczne Stowarzyszenia Teologów Moralistów. http://teologiamoralna.pl/forum-bioetyczne/problematyka-in-vitro/ (28.05.2016).

50 Por. Jan Pawe $\nmid$ II, Adhortacja apostolska Reconciliatio et paenitentia, nr 18.

${ }^{51} \mathrm{~J}$ a n P a w eł II, List do kapłanów na Wielki Czwartek 2002 roku (Watykan, 17.03.2002), „L’Osservatore Romano” wyd. pol. 23 (2002) nr 5, s. 10; Tenże, Encyklika Veritatis splendor, nr 95.

${ }^{52}$ Por. J a n P a w e 1 II, Przem. Posługa kapłańska w sakramencie pojednania, dz. cyt., s. 44; W. J u s z c z a k, Psychoterapeutyczny aspekt sakramentu spowiedzi, Kraków 2009. 
wpływu złych duchów, aż po opętanie człowieka ${ }^{53}$, czy też odpowiednia pomoc penitentom dręczonym przez skrupuły ${ }^{54}$. Zachęcając do zdobywania wiedzy potrzebnej w tych przypadkach, dokument podkreśla, że należy łączyć z nią ,głęboką duchowość, ożywioną przez modlitewny kontakt z Chrystusem, Mistrzem i Odkupicielem"55.

Na zakończenie warto wspomnieć o jeszcze jednym aspekcie papieskiej troski o kapłanów jako szafarzy sakramentu miłosierdzia. Obok omówionych wyżej pouczeń i wskazań, Benedykt XVI przy różnych okazjach dziękował spowiednikom za ich ofiarność i trud posługi w konfesjonale. Jego proste słowa podziękowań brzmią jeszcze bardziej przekonująco w świetle raczej mało znanego faktu. Po śmierci jednego z penitencjarzy, o. Mariusza Paczóskiego OFM Conv, podczas wieczornej prywatnej wizyty w kościele św. Szczepana Abisyńczyków w Watykanie, Benedykt XVI modlił się przy trumnie zmarłego spowiednika. Ten punkt, który do swojego planu dnia dopisał 85 letni Papież, mówi bardzo wiele ${ }^{56}$.

\section{Streszczenie}

Ogłaszając Nadzwyczajny Jubileusz Miłosierdzia papież Franciszek wzywał, by na nowo postawić $\mathrm{w}$ centrum sakrament pokuty i pojednania. Zadanie to powierzył w szczególności spowiednikom. Od ich permanentnej formacji, zależeć będzie

53 Wskazówki praktyczne służące rozpoznawaniu źródła problemów penitenta zawierają publikacje dotyczące posługi kapłanów egzorcystów. Por. np. G. A m o r th, A. Mu s ole s i, Atak złego. Jak rozpoznać zło i jak się z niego wyzwolić, (tłum. A. Zielińska), Kraków 2012; F. B a m o n t e, Opętanie i egzorcyzm. Jak rozpoznać przebiegłego szatana, (tłum. K. Stopa), Kielce 2008; G. M o r a n d, Egzorcyzmy, (tłum. K. Pamięta), Warszawa 2005; M.-A. F o n te 11 e, Egzorcyzm w nauczaniu i posłudze Kościoła katolickiego, (tłum. J. Jęraszek), Ząbki 2003.

${ }^{54}$ Por. W. K róli k o w s k i (red.), Świat moralnych lęków. Wokół „Reguł o skrupułach" św. Ignacego Loyoli, Kraków 2010; E. D z i a ł a, Skrupulatom na ratunek, Poznań 2002.

${ }_{55}$ Kongregacja ds. Duchowieństwa, Kapłan-szafarz miłosierdzia Bożego, nr 63.

56 Por. Watykan: modlitwa Benedykta XVI przy trumnie polskiego penitencjarza (22.06.2012), http://pl.radiovaticana.va/storico/2012/06/22/watykan:_modlitwa_benedykta_xvi_przy_trumnie_polskiego_penitencjarza/pol-598818 (28.05.2016). 
w dużej mierze realizacja tego zadania. Niniejszy artykuł przypomina najważniejsze działania na tym polu, które podjął papież Benedykt XVI. Najpierw autor podkreśla rolę dorocznych spotkań papieża z Penitencjarią Apostolską. Następnie wskazuje na wypowiedzi z Roku Kapłańskiego. Na koniec omawia najważniejsze wskazania dokumentu Kongregacji ds. Duchowieństwa Kapłan - szafarz mitosierdzia Bożego.

\section{Benedict XVI concern about priests as Ministers of the Sacrament of Mercy Summary}

Announcing the Extraordinary Jubilee of Mercy, the Pope Francis called for again put in the center the sacrament of penance and reconciliation. This task was entirely entrusted to the confessors. The success of this task will be largely dependant on their permanent formation. The following article presents the most prominent actions that has been taken in this field by the Pope Benedict XVI. First, the author stresses the role of the annual meetings of the Pope with the Apostolic Penitentiary. Next, he points to the speeches of the Year for Priests. Finally, he discusses the most important Indications of document of the Congregation for the Clergy "The priest, minister of divine mercy".

(Ttum. Iwona Badaczewska)

Slowa kluczowe: Benedykt XVI, sakrament miłosierdzia, spowiednik

Key words: Benedict XVI, Sacrament of Mercy, Confessor

Nota 0 autorze: Ks. dr hab. Zbigniew Wanat jest adiunktem w katedrze Teologii Moralnej i Duchowości na Wydziale Teologicznym UMK w Toruniu. Główne obszary jego badań to problematyka sumienia, sakrament pokuty i pojednania oraz zagadnienia bioetyczne.

\section{Bibliografia:}

Amorth G., Musolesi A., Atak złego. Jak rozpoznać zło i jak się z niego wyzwolić, tłum. A. Zielińska, Kraków 2012.

Augustyn J., Naśladować Jezusa w konfesjonale, w: Tenże (red.), Sztuka spowiadania. Poradnik, wyd. 3 rozszerzone, Kraków 2012, s. 253-261. 
Balicki L., Po co te dyskusje o spowiedzi dzieci! „Przewodnik Katolicki”, http:// www.przewodnik-katolicki.pl/pg/pl/komentarze/ks_lech_bilicki/po_co_te_ dyskusje_o_spowiedzi_dzieci.html (12.05.2014).

Bamonte F., Opętanie i egzorcyzm. Jak rozpoznać przebiegłego szatana, tłum. K. Stopa, Kielce 2008.

Benedykt XVI, Przem. Z gorliwościa wypetniajcie ważna postugę w konfesjonale (Watykan, 19.02.2007), „L'Osservatore Romano” wyd. pol. 28 (2007) nr 5, s. 43. Benedykt XVI, Adhortacja apostolska Sacramentum caritatis (Watykan, 22.02.2007).

Benedykt XVI, Przem. Kapłan jest narzędziem miłosiernej miłości Boga (Watykan, 16.03.2007), „L'Osservatore Romano” wyd. pol. 28 (2007) nr 6, s. 30.

Benedykt XVI, Przem. Bierzcie przykład z tak wielu świętych spowiedników (Watykan, 7.03.2008), „L'Osservatore Romano” wyd. pol. 29 (2008) nr 4, s. 34.

Benedykt XVI, List na rozpoczęcie Roku Kapłańskiego z okazji 150. rocznicy «dies natalis» Świętego Proboszcza z Ars (Watykan, 16.06.2009), „L'Osservatore Romano" wyd. pol. 30 (2009) nr 7-8, s. 5.

Benedykt XVI, Hom. Tajemnica miłości Boga do ludzi (Watykan, 19.06.2009), „L'Osservatore Romano” wyd. pol. 30 (2009) nr 9, s. 37.

Benedykt XVI, Przem. Bądźcie wiernymi przyjaciółmi Jezusa jak Ojciec Pio (San Giovanni Rotondo, 21.06.2009), „L'Osservatore Romano” wyd. pol. 30 (2009) nr 10, s. 15.

Benedykt XVI, Kat. Św. Jan Maria Vianney (Castel Gandolfo, 5.08.2009), „L'Osservatore Romano” wyd. pol. 30 (2009) nr 10, s. 30.

Benedykt XVI, Przem. Jesteśmy przyjaciólmi tych, którzy znają Boga, i tych, którzy Go jeszcze nie znaja (Watykan, 21.12.2009), „L'Osservatore Romano” wyd. pol. 31 (2010) nr 2, s. 39-40.

Benedykt XVI, Przem. «Kryzys» sakramentu pokuty jest wyzwaniem przede wszystkim dla kapłanów (Watykan, 11.03.2010), „L'Osservatore Romano” wyd. pol. 31 (2010) nr 5, s. 34.

Benedykt XVI, Kat. Kapłani darem dla Kościoła i świata (Watykan, 5.05.2010), „L'Osservatore Romano” wyd. pol. 31 (2010) nr 7, s. 50.

Benedykt XVI, Adhoratacja apostolska Verbum Domini (Watykan, 30.09.2010).

Benedykt XVI, List do seminarzystów (Watykan, 18.10.2010), „L'Osservatore Romano" 31 (2010) nr 11, s. 5.

Benedykt XVI, Przem. W kwestii zła w człowieku i historii ostatnie słowo należy do Boga (Watykan, 25.03.2011), „L'Osservatore Romano” wyd. pol. 32 (2011) nr 5, s. 24. 
Benedykt XVI, Przem. Spowiedź sakramentalna siła nowej ewangelizacji (Watykan, 9.03.2012), „L'Osservatore Romano” wyd. pol. 33 (2012) nr 5, s. 48.

Bryl D., Zapłodnienie in vitro w kontekście sakramentu pojednania i pokuty, „Teologia i Moralność" (2011) nr 2, s. 69-90.

Da Cervinara T., Ojciec Pio - spowiednik. Nadzwyczajny i wyjątkowy ożywiciel „martwych dusz”, w: Ojciec Pio. Heroiczny spowiednik (opracowanie zbiorowe), tłum. S. Kafel, Kraków 2002, s. 9-15.

Długosz A., Moja pierwsza spowiedź, Radom 2008.

Działa E., Skrupulatom na ratunek, wyd. 2, Poznań 2002.

Dziewicki M., Pierwsza spowiedź czyli doświadczenie miłości, „Różaniec” (2009) nr 4, s. 24-25.

Fontelle M.-A., Egzorcyzm w nauczaniu i posłudze Kościoła katolickiego, tłum. J. Jęraszek, Ząbki 2003.

Forum Bioetyczne Stowarzyszenia Teologów Moralistów. http://teologiamoralna. $\mathrm{pl}$ /forum-bioetyczne/problematyka-in-vitro/ (28.05.2016).

Franciszek, Bulla Misericordiae Vultus (Watykan, 11.04.2015).

Gryz K., Rozgrzeszenie po zabiegu in vitro. Głos w dyskusji, „Teologia i Moralność” (2010) nr 2, s. 25-36.

Jan Paweł II, Adhortacja apostolska Reconciliatio et paenitentia (Watykan, 2.12.1984).

Jan Paweł II, Adhortacja apostolska Pastores dabo vobis (Watykan, 25.03.1992).

Jan Paweł II, Przem. Posługa kapłańska w sakramencie pojednania (Watykan, 27.03.1993), „L'Osservatore Romano” 14 (1993) nr 5-6, s. 44.

Jan Paweł II, Encyklika Veritatis splendor (Watykan, 6.08.1993).

Jan Paweł II, Przem. Rola kapłana w sakramencie pokuty (Watykan, 18.03.1995), „L'Osservatore Romano” wyd. pol. 16 (1995) nr 5, s. 16.

Jan Paweł II, Przesł. Sakrament pokuty wielkim darem Bożego miłosierdzia (Watykan, 22.03.1996), „L'Osservatore Romano” wyd. pol. 17 (1996) nr 6, s. 12.

Jan Paweł II, List apostolski Novo millennio ineunte (Watykan, 6.01.2001).

Jan Paweł II, List apostolski Misericordia Dei (Watykan, 7.04.2002).

Jan Paweł II, List do kapłanów na Wielki Czwartek 2002 roku (Watykan, 17.03.2002), „L'Osservatore Romano” wyd. pol. 23 (2002) nr 5, s. 10.

Jan Paweł II. Przem. O godne i owocne sprawowanie sakramentu pokuty (Watykan, 28.03.2003), „L'Osservatore Romano” wyd. pol. 24 (2003) nr 6, s. 38.

Jan Paweł II, Encyklika Ecclesia de Eucharistia (Watykan, 17.04.2003).

Jan Paweł II, Przesł. Eucharystia i sakrament pojednania (Rzym-Poliklinika Gemelli, 8.03.2005), „L'Osservatore Romano” wyd. pol. 26 (2005) nr 5, s. 47. 
Jeżyna K., Sakrament pokuty źródłem nowej ewangelizacji, „Roczniki Teologiczne” 53 (2006) z. 3, s. 25-38.

Jurczyk B., Potrójna rola kapłana w sakramencie pokuty, w: K. Glombik (red.),

Sakrament pokuty wobec problemów współczesności, Opole 2011, s. 217-238.

Juszczak W., Psychoterapeutyczny aspekt sakramentu spowiedzi, Kraków 2009.

Katechizm Kościoła Katolickiego (Watykan, 11.10.1992).

Kazania proboszcza z Ars. Wybór homilii niedzielnych $i$ świątecznych św. Jana Marii Vianney, Patrona Kapłanów, wyd. 5, Warszawa 2009.

Kongregacja ds. Duchowieństwa, Kapłan - szafarz miłosierdzia Bożego. Pomoce dla spowiedników i kierowników duchowych (Watykan, 9.03.2011), tłum. J. Królikowski, wyd. Biblos, Tarnów 2011.

Kongregacja ds. Kultu Bożego, Odpowiedź Quaenam sunt dispositiones odnośnie do norm dotyczących czasu sprawowania sakramentu pokuty (31.07.2001), „Notitiae” 37 (2001), s. 259-260.

Konik-Korn M., Czy dziecko może zgrzeszyć? „Niedziela” nr 21 (2012) s. 24-25.

Madejczyk D., Kiedy pierwsza spowiedź? „Przewodnik Katolicki” nr 20 (20.05.2012), s. 40-41.

Morand G., Egzorcyzmy, tłum. K. Pamięta, Warszawa 2005.

Orzeszyna J., Posłannictwo i obowiąki spowiednika w nauczaniu Jana Pawła II, w: Człowiek droga Kościoła. Moralne aspekty nauczania Jana Pawła II, red. K. Gryz, Kraków 2004, s. 493-506.

Pawłowicz J. J., Spowiedź osób związanych ze sztucznym zapłodnieniem „, in vitro”, „Poradnik Spowiednika” grudzień 2013, s. 7-33.

Posługa spowiedników $w$ realizacji powołania matżeńskiego, red. E. Bogurad, B. Bassa, K. Wolski, Łomianki 1999.

Selejdak R., Znaczenie sakramentu pokuty w życiu i posłudze kapłana oraz w formacji seminarzystów, „Warszawskie Studia Teologiczne”, 25(2012) nr 2, s. 206-209.

Sobór Trydencki, Sesja VI rozdz. 6, Sesja XIII rozdz. 7, Denzinger-Schönmetzer.

Szymański J., Kapłan sługa sakramentalnego pojednania, „Ateneum Kapłańskie",t. 154 (2010) z. 3, s. 249-260.

Św. Alfons Maria de Liguori, Praktyczny przewodnik dla spowiednika. Aby dobrze sprawowat swoja postugę, tłum. K. Stopa, Kraków 2010.

W. Królikowski (red.), Świat moralnych lęków. Wokół „Reguł o skrupułach” św. Ignacego Loyoli, Kraków 2010.

Wanat Z., Kapłan-spowiednik - sługa miłości potężniejszej niż grzech, „Teologia i Człowiek", (2006) nr 1-2, s. 271-288.

Wanat Z., Kapłan - stuga Bożego miłosierdzia, „Studia Theologica Varsaviensia”, 52(2014) nr 2, 83-102. 
Watykan: modlitwa Benedykta XVI przy trumnie polskiego penitencjarza (22.06.2012), http://pl.radiovaticana.va/storico/2012/06/22/watykan:_modlitwa_benedykta_xvi_przy_trumnie_polskiego_penitencjarza/pol-598818 (28.05.2016).

Wójcik B., Biomedycyna i konfesjonat, w: J. Augustyn (red.), Sztuka spowiadania. Poradnik, wyd. 3 rozszerzone, Kraków 2012, s. 123-136. 